\title{
Organic matter content in riparian areas of soil composed of woody vegetation and grass and its effects on pesticide adsorption
}

\author{
Terencio Rebello de Rebello Jr. ${ }^{1,2} \cdot$ Fernando Rodrigo Bortolozo ${ }^{1,2} \cdot$ Lucilia Maria Parron $^{1,2}$
}

Received: 10 July 2018 / Accepted: 27 October 2018 / Published online: 3 November 2018

(c) The Author(s) 2018

\begin{abstract}
Purpose Riparian zones are identified as mitigation areas of agricultural pollutants to river ecosystems. However, the mitigation mechanisms of these pollutants remain unclear mainly on the effects of different types of riparian vegetation and its organic matter content in the pollutants removal process. This study aims to assess the content of organic matter in soils composed of woody vegetation and grass and its effects on four pesticides adsorption. Adsorption studies were conducted in soil collected in riparian vegetation areas composed of grass and trees under the influence of an agricultural area.

Methods The analyses were performed in 21 shakers containing $100 \mathrm{~g}$ soil and a $\mathrm{L}$ of water previously contaminated with pesticide that were stirred for 30,60,120, 240,360, 720, and $1440 \mathrm{~min}$. A study was made of maximum adsorption capacity using the time $360 \mathrm{~min}$ and the concentrations of 5, 20, 40, and $50 \mu \mathrm{g} \mathrm{L}-1$.

Results The soils of woody vegetation areas had a higher concentration of organic matter as compared with grass areas, and time 360 min achieved the highest adsorption capacity with minimum values of $84 \%$ adsorption for the area of land made up of trees and $67 \%$ for grass areas. The soils of woody vegetation areas had a higher concentration of organic matter as compared with grass areas, time $360 \mathrm{~min}$.

Conclusion The best adsorption capacity was obtained with minimal adsorption amounts of $84 \%$ to the area of soil composed of $67 \%$ for trees and grass areas.
\end{abstract}

Keywords Riparian zones $\cdot$ Pesticides $\cdot$ Organic matter $\cdot$ Water contamination $\cdot$ Adsorption

\section{Introduction}

With the constant expansion of the world population, there is also an increase in demand for food and raw materials. An estimate of the United Nations (2008) stated that in 2050, the number of people on the planet will be approximately nine billion. This constant expansion of the population has driven the development of new technologies in the agribusiness segment, such as nanotechnology, biotechnology, natural resource management, and new pesticides.

Pesticides are substances with toxic action and include herbicides, insecticides, miticides, fungicides, and others (EXTOXNET 1996; Spark and Swift 2002); Illani et al.

Terencio Rebello de Rebello Jr. terenciojunior@gmail.com

1 Universidade Federal da Bahia, Salvador, Bahia, Brazil

2 Forests Department, Brazilian Agricultural Research Corporation-EMBRAPA, Colombo, PR 83411-000, Brazil
2005). These chemical compounds have active ingredients formulated to prevent, combat, or destroy unwanted species or diseases that might interfere with agricultural production or in the storage and transport of planted crops (McBride 1994; Jakelaitis et al. 2006).

The interaction, presence, or removal of pesticides in the soil, as well as effective action for which the product is applied, are aspects influenced by different physical, chemical, and biological processes (McBride 1994; Freire et al. 2004; Coelho and Bernardo 2012). These processes often occur simultaneously, resulting in the complexity of this relationship pesticide-soil (Reemtsma et al. 1999; Lavorenti et al. 2003; Sarwar et al. 2018).

When applied to soil, pesticides can be degraded by chemical reactions, photolysis, or the action of microorganisms (McBride 1994; Zheng and Cooper 1996; Carmo et al. 2013; Correia and Langenbach 2006). However, molecules with high persistence can remain in the environment without undergoing any change. These molecules are subject to sorption and desorption of soil particles to leaching and 
may reach the saturated zone of the soils. Or they could be leached into rivers and lakes. In aquatic environments, pesticides may undergo sorption in dry sediment or water can be absorbed by plants, fish, and other aquatic fauna representatives (Mitchell and Simpson 2013).

The adsorption and desorption of organic compounds such as pesticides in the soil are the most important processes related to soil and water contamination by these compounds (Barriuso et al. 1992). In this context, the organic matter in the soil can have great influence on the evaluation of the soil mobility of the pesticides, which is important to the retention of these compounds in the agricultural area by preventing them to be leached into rivers, lakes, and underground water.

In tropical and subtropical soils, organic matter has a close relationship with the other physical, chemical, and biological properties of soil (Correia and Langenbach 2006). Thus, the sustainable management of soil organic matter is fundamental to maintaining the productive capacity of the soil in the long term. The management effect on stocks of organic matter depends on the type of soil (Aguiar et al. 2014).

The content of organic matter is an important factor in the soil, because strongly affects fertility by increasing the availability of nutrients for plants, the improvement of its structure and water-holding capacity, and also by the accumulation of toxic action phases and heavy metals. For McBride (1994), the organic matter in association with the clay has an extremely important influence on the physical and chemical properties of soil. This includes: maintenance of the pore structure accompanied by improved water retention, agricultural nutrient retention by the exchange cation, release nitrogen, phosphorus, sulfur and trace elements by mineralization, adsorption of potentially toxic organic and others (Celis et al. 1998; Ahmad et al. 2001; Carmo et al. 2013, Arne et al. 2019). Thus, the present study aims to assess the content of organic matter in riparian areas of soil composed of grass and trees with a view to its influence on pesticide adsorption capacity by these soils.

\section{Methods}

\section{Characteristics of the study soil}

The study of soil comes from two areas of riparian vegetation being one composed of trees and other soils (per gram) were collected at a depth of $0-20 \mathrm{~cm}$, the soil samples were analyzed in the laboratory of the Brazilian Agricultural Research Corporation-Embrapa Forestry and soil laboratory of the Federal University of Parana (UFPR) to determine their chemical composition and organic matter content. Adsorption studies were performed in Hydrogeological Research Laboratory of the Federal University of Parana. All soils collected were analyzed for presence of pesticides before the start of the tests.

\section{Adsorption tests}

The soils were collected from areas of forest preservation and free of pesticide application. For confirmation, pesticide analyses were performed to determine the presence of potential interferents in the sample. The soils were then dried in an oven at $80^{\circ} \mathrm{C}$ for $24 \mathrm{~h}$.

For the tests standards were used: atrazine, fluazifop$p$-butyl, lactofen, and chlorpyrifos at the concentration of $10 \mu \mathrm{g} \mathrm{L}^{-1}$. The standards were added in 21 shakers containing $100 \mathrm{~g}$ soils with high organic matter content (from a riparian vegetation area composed of trees) and 21 shakers containing $100 \mathrm{~g}$ soil low in organic matter (from a riparian vegetation area comprising for grasses) in each shaker was added $1 \mathrm{~L}$ of purified water in a milli- $\mathrm{Q}$ water purification system (Millipore, Bedford, MA).

In shakers were then covered with aluminum paper to prevent photo-degradation of pesticides, and kept at room temperature with constant stirring for times 30, 60, 120, 240, 360, 720, and $1440 \mathrm{~min}$, and at the end of each time, the samples were filtered using a cellulose acetate filter with porosity of $0.45 \mu \mathrm{m}$ and analyses subsequently performed immediately in water.

\section{Maximum adsorption capacity tests}

For maximum adsorption capacity, assays were used concentrations of $5,20,40$, and $50 \mu \mathrm{g} \mathrm{L}^{-1}$ of atrazine, fluazifop$p$-butyl, lactofen, and chlorpyrifos. For these tests, the temperature used was $25^{\circ} \mathrm{C}$ (average temperature corresponding to the areas of study). Pesticides were added to 15 shakers and maintained with agitation, being withdrawn at each time a sample for analysis.

The calculations of linear isotherms were made by relationship between q CEQ. They are

$q=a+b\left(c_{\mathrm{qe}}\right)$.

This linear regression method can be used to find the slope $(b)$ and the intercept $(a)$ is an ideal model for studies with adsorbents that exhibit linear isotherms at low concentrations, as in the present study.

\section{Sample extraction}

The extraction protocol was optimized from studies developed by Lacorte et al. (2000) and Aguiar et al. 2015. In a sample of $1 \mathrm{~L}$ was added $0.1 \mu \mathrm{g}$ of Atrazine-D5 (99\% purity, 
Bellefonte, PA, USA) as a standard replacement before extraction. The samples were first filtered using a cellulose membrane with a porosity of $0.45 \mathrm{~mm}$ and $47 \mathrm{~mm}$ diameter (Millipore Merck-Darmstadt, Germany).

$1 \mathrm{~L}$ of water sample was extracted using extraction cartridges C18 SPE solid phase (Milford, MA, USA). The cartridges were cleaned first with $6 \mathrm{ml}$ of ethyl acetate, $6 \mathrm{ml}$ methanol, and $6 \mathrm{ml}$ of purified water (Milli-Q, Millipore, Bedford, MA) and samples were then percolated through a vacuum system (JT Baker-Phillipsburg, NJ) at a flow rate of $6 \mathrm{ml} / \mathrm{min}$.

After that, the cartridges were dried under vacuum for $15 \mathrm{~min}$ to remove excess water. Then, extraction was performed with $6 \mathrm{ml}$ of ethyl acetate and $6 \mathrm{ml}$ of methanol. The extract was dried with a gentle stream of nitrogen using a dry block $\left(40^{\circ} \mathrm{C}\right.$, Marconi, SP, BRA), and reconstituted in $100 \mathrm{ml}$ of ethyl acetate. The samples were transferred to test tubes for analytical gas chromatography-mass spectrometry.

\section{Gas chromatography-mass spectrometry (GC-MS)}

The GC-MS was performed using a Varian gas chromatograph Varian 431. GC MS 220 coupled to an ion trap mass spectrometer equipped with a capillary column VF $5 \mathrm{~ms}$ $(30 \times 0.25 \mathrm{~mm}$ and $25 \mathrm{~mm}$ film thickness). The GC oven was programmed to $90^{\circ} \mathrm{C}$, held for $0.5 \mathrm{~min}$, then heated to $160{ }^{\circ} \mathrm{C}$ (for $4 \mathrm{~min}$ ) at $15{ }^{\circ} \mathrm{C} \mathrm{min}-1$, and heated again to $280^{\circ} \mathrm{C}$ (hold for $10 \mathrm{~min}$ ) $20^{\circ} \mathrm{C} \mathrm{min}{ }^{-1}$. The sources of ions and GC interface were $280^{\circ} \mathrm{C}$ and $200{ }^{\circ} \mathrm{C}$, respectively. The mass spectrometer ion trap was operated on impact ionization of electrons with an energy of $70 \mathrm{eV}$ ionization and emission of $300 \mathrm{~mA}$ current. The helium at a constant flow rate of $1.0 \mathrm{ml} \mathrm{min}^{-1}$ was used as the carrier gas. The injection volume was $1 \mu \mathrm{L}$ in a splitless mode $(1 \mathrm{~min})$ with the injector temperature at $250^{\circ} \mathrm{C}$. From the collision-induced dissociation (MS/MS), three mass fragment ions were selected for each compound atrazine $\left(\mathrm{m} / \mathrm{z}, 122^{*}, 132\right.$, and $200)$, chlorpyrifos $\left(\mathrm{m} / \mathrm{z} 258^{*}, 286\right.$, and 314$)$, fluazifop butylp $\left(\mathrm{m} / \mathrm{z} 254,238^{*}\right.$, and 282), and lactofen $\left(\mathrm{m} / \mathrm{z} 223^{*}, 300\right.$, and 344), and the main fragment ions used as the precursor ion mass. The mass fragment ions labeled were used for quantification analysis and the other two were used for structural confirmation. The stock solutions were prepared for all agrochemicals (99\% purity, Sigma-Aldrich, Missouri, USA) $10 \mathrm{mg} \mathrm{ml}^{-1}$ in ethyl acetate and were maintained at $-4^{\circ} \mathrm{C}$.
Atrazine-D5 was verified with the following ions $\mathrm{m} / \mathrm{z}$ $127^{*}, 139$, and 205 . The calibration curve was performed with diluted standards between 0.01 and $30 \mu \mathrm{g} \mathrm{L}^{-1}$. Calibration curves resulted in correlation coefficients of 0.99 and relative standard deviation of less than $9 \%(n 4)$ for all compounds. The lower point of quantification was $0.01 \mu \mathrm{g} \mathrm{L}^{-1}$, where all compounds showed significant signs. Recovery studies were performed with a mixture of five samples of agrochemical pesticides free groundwater at a concentration of $1 \mu \mathrm{g} \mathrm{L}^{-1}$ and recovery values ranged $83-97 \%$ with a standard deviation of less than $12 \%(n 5)$ for all analyses.

The protocols used in accordance with SANCO/10232/2006 EU (European Commission, 2006). The identification and confirmation of the target compounds were made based on the following criteria: (i) the retention time deviation from a standard of less than $2 \mathrm{~s}$; (ii) three characteristics $\mathrm{m} / \mathrm{z}$; and (iii) features of intensities $\mathrm{m} / \mathrm{z}$ compared with standard $\mathrm{m} / \mathrm{z}$ (not more than $15 \%$ variation).

The significance of different samples was tested by analysis of variance (ANOVA). When significant probability was detected $(p<0.05)$, means were compared by Tukey's test, and multiple comparisons were performed testing to determine which buffer zone width. They were especially different based on the concept of Least Significant Difference (LSD) and were determined at 5\%.

To calculate the percentage removal, the initial concentration in the solution, which was considered as $100 \%$ (A), was used. For the calculation of the removal of pesticides studied and the result found after stirring times (B), the percent removal was calculated by the difference between $\mathrm{A}$ and $\mathrm{B}$.

\section{Results and discussion}

The physical characteristics of soils are presented in Table 1 . The clay concentration was $15 \mathrm{~g} \mathrm{~kg}^{-1}$, and the sand was of $12 \mathrm{~g} \mathrm{~kg}^{-1}$ and $13 \mathrm{~g} \mathrm{~kg}^{-1}$ silt. The average amount of organic matter present in soil consisting of woody vegetation was $370.9 \mathrm{~g} \mathrm{~kg}^{-1}$; as for the land areas composed per gram, the amount of organic matter was observed $99.10 \mathrm{~g} \mathrm{~kg}^{-1}$. The observed values of $\mathrm{pH}$ for the samples collected were between 5.27 and 5.8.

For comparative analysis of soils containing low and high organic matter content, significant differences were observed for all times used (Table 1). Analyzing the pesticide concentrations between the times of $30 \mathrm{~min}, 1 \mathrm{~h}$,
Table 1 Characterization of samples analyzed for organic carbon concentration, organic matter, sand, silt, and clay

\begin{tabular}{lcclll}
\hline & Organic carbon $\left(\mathrm{g} \mathrm{kg}^{-1}\right)$ & Organic matter $\left(\mathrm{g} \mathrm{kg}^{-1}\right)$ & Sand $\left(\mathrm{g} \mathrm{kg}^{-1}\right)$ & Silte $\left(\mathrm{g} \mathrm{kg}^{-1}\right)$ & Clay $\left(\mathrm{g} \mathrm{kg}^{-1}\right)$ \\
\hline ATMO & $215.6( \pm 0.7)$ & $370.9( \pm 1.3)$ & 12 & 13 & 15 \\
BTMO & $57.5( \pm 0.7)$ & $99.1( \pm 1.2)$ & 11 & 12 & 13 \\
\hline
\end{tabular}

ATMO high content of organic matter, BTMO low organic matter content 
$2 \mathrm{~h}$, significant differences were observed between them, for all pesticides analyzed using both low concentration of organic matter when high concentrations of organic matter (Tukey, $p<0.05$ ). There were no significant differences between $12 \mathrm{~h}$ and $24 \mathrm{~h}$ times for atrazine and chlorpyrifos both low organic matter and high organic matter content. (Tukey, $p>0.05$ ) For fluazifop and lactofen pesticides, there were no significant differences between $6 \mathrm{~h}, 12 \mathrm{~h}$, and $24 \mathrm{~h}$. The pesticide fluazifop demonstrated no significant differences between $4 \mathrm{~h}$ times a $24 \mathrm{~h}$.

For pesticides studied the soil with higher content of organic matter from riparian areas composed of woody vegetation, they showed the best results, being that the balance in the adsorption process occurred only after $360 \mathrm{~min}$ of agitation $(6 \mathrm{~h})$. Thus, the time $360 \mathrm{~min}$ was used for maximum adsorption capacity test (Fig. 1).

For the time $360 \mathrm{~min}$, atrazine had a $84 \%$ adsorption percentage in riparian area of soil composed of woody vegetation and $67 \%$ for grass areas. Chlorpyrifos had already obtained $91 \%$ adsorption in areas with woody vegetation and $77 \%$ for areas with grasses. For fluazifop areas with woody vegetation removal achieved $94 \%$ and $71 \%$ in areas with vegetation composed per grasses. The lactofen achieved $86 \%$ removal in areas with woody vegetation and $61 \%$ for areas with vegetation consists of grasses (Fig. 1).

In studies of maximum adsorption capacity (Fig. 2) was identified isotherms a linear model, fluazifop pesticide had a higher adsorption coefficient $\mathrm{Kd}(\mathrm{L} / \mathrm{kg})$ of 259.29 , followed by chlorpyrifos with 140.70 , since the pesticide atrazine and lactofen obtain one low value being 54.50 and 49.31, respectively.

The soil riparian areas composed of woody vegetation obtained the best results in the composition of organic matter in relation with the area of the compound per grasses soil. This difference can be explained by observing the larger amount of promoted vegetable waste deposition on the trees. Otherwise, the density of planted trees reduces the impact of raindrops on the soil promoting greater stability and reducing the transport of sediment and organic matter itself.

The riparian soil region composed of trees, which had a higher amount of organic matter obtained a better retention of pesticides studied compared with the areas with vegetation soil composed per grasses with a reduction of more than $84 \%$ for the pesticides against $67 \%$ for grass areas on time $360 \mathrm{~min}$.

In isotherms, studies found a linear model of adsorption due to the low concentration of the compounds studied, the pesticide fluazifop showed the most adsorption capacity followed by chlorpyrifos, atrazine and lactofen. Other studies have found similar results, Oliver et al. (2005) and Ling et al. (2006) studied the kinetics of pesticides in different soil types and found a positive correlation between the pesticides and adsorption to organic carbon. This data also are consistent with studies in the field made by Katsoyiannis and Samara (2007) and Aguiar et al. (2015) in which the pesticide was fluazifop with a higher rate of removal, followed by chlorpyrifos, lactofen and atrazine, and in environmental factors other than influence of organic matter degradation of these compounds.
Fig. 1 Pesticide removal efficiency atrazine (a), chlorpyrifos (b), fluazifop (c), and lactofen (d) in soils containing high concentrations of organic matter (filled circle) and low concentrations of organic matter (filled square)
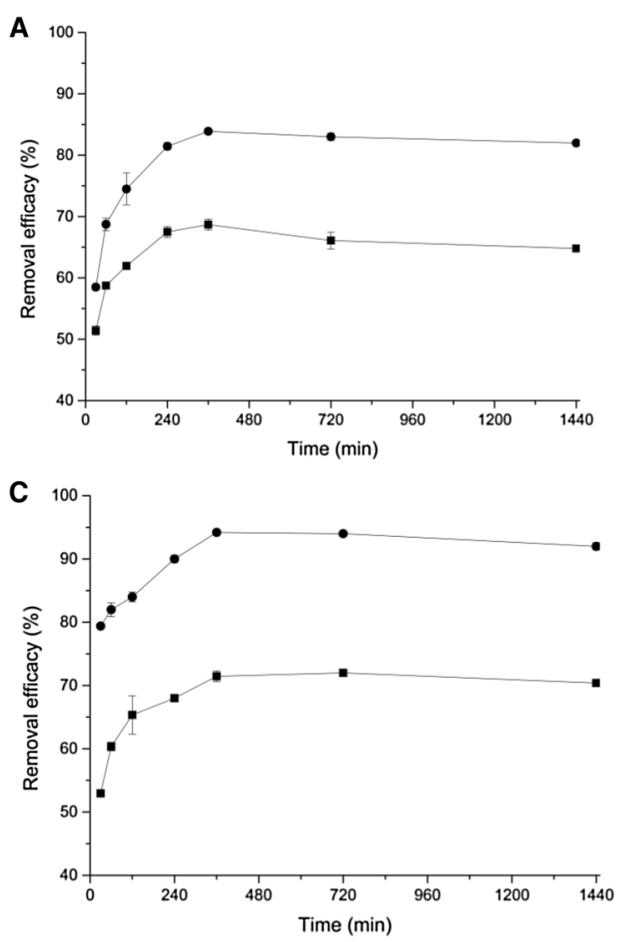
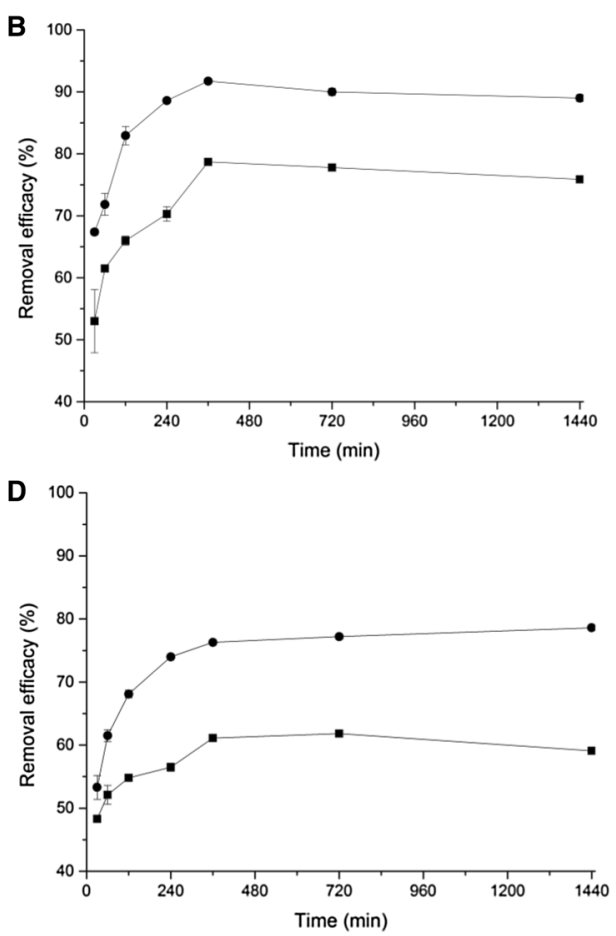

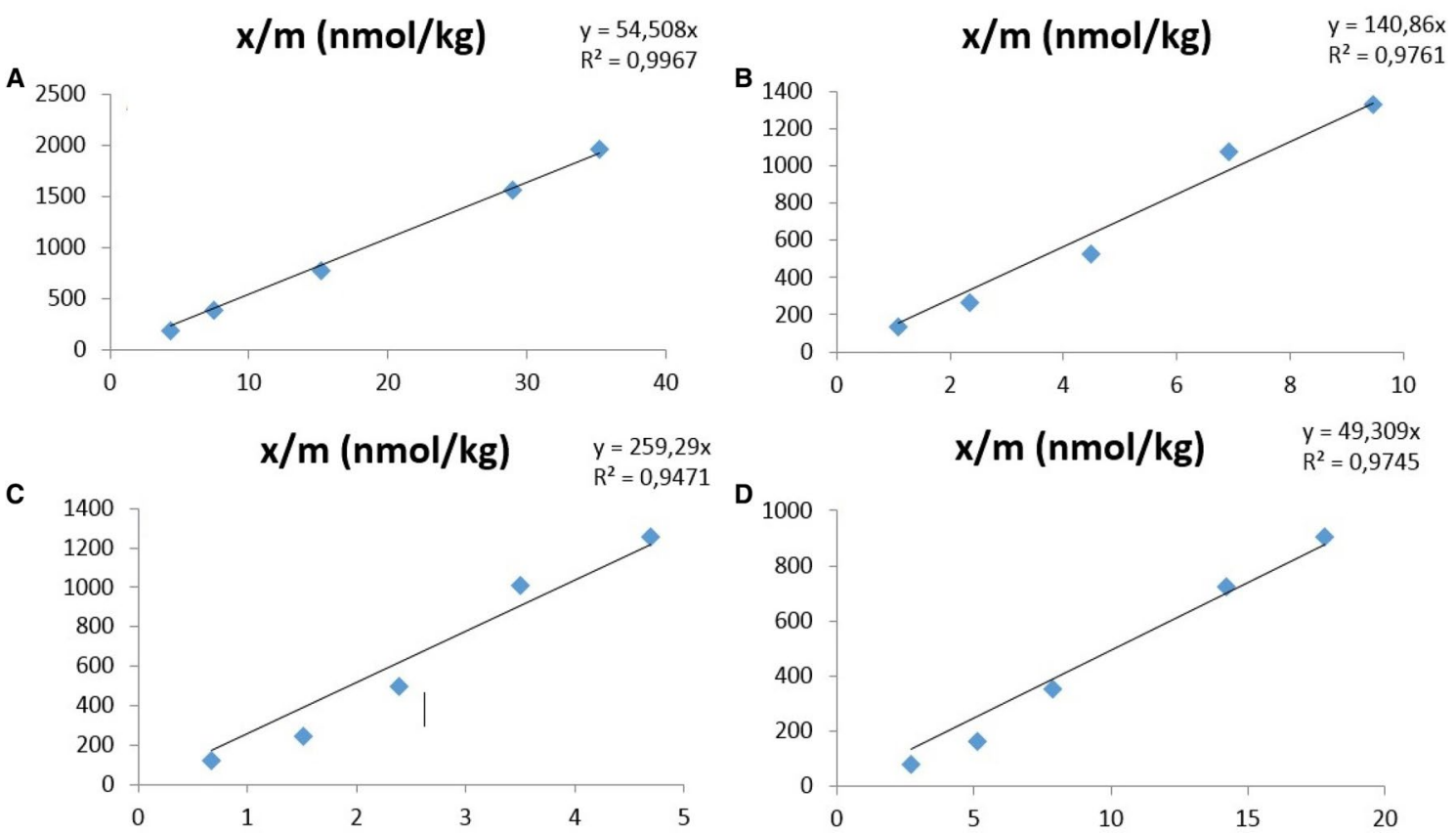

Fig. 2 Adsorption isotherms for atrazine (a), chlorpyrifos (b), fluazifop (c), and lactofen (d) riparian area of soil composed of trees containing high concentrations of organic matter

Due to the low $\mathrm{pH}$ of the soil studied, there was an increase in the protonation of pesticides molecules, causing most of them would meet in the neutral form and, consequently, to increase its sorptive organic matter. In neutral form, the sorption becomes more dependent on the organic matter to the soil mineral fraction.

Soils with low organic matter content have a high negative charge making it less able to accommodate the neutral species of pesticides studied with the solid phase. Furthermore, the release of organic matter into the solutions (soil, water, pesticides, etc.) makes it more efficient for soils to accommodate molecules of pesticides, causing the sorption of the compound increases and decreases of leaching.

\section{Conclusion}

In the present study, soil materials with a high content of organic matter presented a higher adsorption index of pesticides studied with $84 \%$ reduction, as the soils with lower content presented a reduction of $67 \%$. In tropical and subtropical soils, organic matter has a close relationship with the other physical, chemical and biological soil properties.

Therefore, sustainable management of soil organic matter is essential to maintaining the productive capacity of the soil and reducing leaching of agricultural pollutants such as pesticides.

Open Access This article is distributed under the terms of the Creative Commons Attribution 4.0 International License (http://creativeco mmons.org/licenses/by/4.0/), which permits unrestricted use, distribution, and reproduction in any medium, provided you give appropriate credit to the original author(s) and the source, provide a link to the Creative Commons license, and indicate if changes were made.

\section{References}

Aguiar TR Jr, Rasera K, Parron M, Brito G, Ferreira T (2014) Nutrient removal effectiveness by riparian buffer zones in rural temperate watersheds: the impact of no-till crops practices. AGR Water Manag 149:74-80. https://doi.org/10.1016/j.agwat .2014.10.031

Aguiar TR Jr, Bortolozo R, Hansel A, Rasera K, Ferreira T (2015) Riparian buffer zones as pesticide filters of no-till crops. Environ Sci Pollut Res 22:7500-7510. https://doi.org/10.1007/s1135 6-015-4281-5

Ahmad R, Kookana RS, Alsto A, Skjemstad O (2001) The nature of soil organic matter affects sorption of pesticides. 1. Relationships with carbon chemistry as determined by 13C CPMAS NMR spectroscopy. Environ Sci Technol 35:878-884. https:// doi.org/10.1021/es001446i

Arne D, Niels T, Michael H, Luis G, Indira N, Wout E, Marie E, Pieter S (2019) Peter G. Distribution of agricultural pesticides in 
the freshwater environment of the Guayas river basin (Ecuador) 646:996-1008. https://doi.org/10.1016/j.scitotenv.2018.07.185

Barriuso E, Baer U, Calvet R (1992) Dissolved organic matter and sorption-desorption of dimefuron, atrazine and carbetamide by soils. J Environ Qual 21:359-367. https://doi.org/10.2136/sssaj 1999.6361659x

Carmo A, Pires B, Oliveira M (2013) Comportamento ambiental e toxidade dos herbicidas atrazina e simazina. Rev Ambient Água 8(12):133-143. https://doi.org/10.4136/ambi-agua.1073

Celis R, Cornejo J, Hermosin C, Koskinen C (1998) Sorption of atrazine and simazine by model associations of soil colloids. Soil Sci Soc Am J 62:165-171. https://doi.org/10.2136/sssaj1998.03615 $995006200010022 \mathrm{x}$

Coelho E, Bernardo L (2012) Removal of atrazine and metabolites through slow filtration by sand and granular activated carbon. Eng Sanit Ambient 17(3):269-276. https://doi.org/10.1590/S1413 $-41522012000300003$

Correia V, Langenbach T (2006) Distribution and decomposition dynamics of atrazine in an ultisol under wet tropical climate conditions. Rev Bras Ciênc Solo 30:183-192. https://doi.org/10.1590/ S0100-06832006000100018

EXTOXNET (1996) Fluazifop-p-butyl. Pesticide information profiles. Extension toxicology. Extension Toxicology Network, p 6-7. http://ace.orst.edu/info/extoxnet/. Accessed Oct 2018

Freire E, Carvalho E, Dores C (2004) Contaminação de águas superficiais e subterrâneas por pesticidas em Primavera do Leste, Mato Grosso, Instituto de Química da Universidade Estadual Paulista. http://hdl.handle.net/11449/105654. Accessed Oct 2018

Illani T, Schulz E, Chefetz B (2005) Interactions of organic compounds with wastewater dissolved organic matter: role of hydrophobic fractions. J Environ Qual 34:552-562. https://doi.org/10.2134/ jeq2005.0552

Jakelaitis A, Vivian R, Santos J, Silva A (2006) Soil residual activity of the commercial mixtures of the herbicides fluazifop-p-butyl and fomesafen under bean tillage and no-tillage systems. Planta Daninha 24(3):533-540. https://doi.org/10.1590/S0100-83582 006000300016

Katsoyiannis A, Samara C (2007) The fate of dissolved organic carbon (DOC) in the wastewater treatment process and its importance in the removal of wastewater contaminants. Env Sci Pollut Res 14:284-292. https://doi.org/10.1065/espr2006.05.302

Lacorte S, Guiffard I, Fraisse D, Barcelo D (2000) Broad spectrum analysis of 109 priority compounds listed in the 76/464/CEE
Council Directive using solid-phase extraction and GC/EI/MS. Anal Chem 72:1430-1440. https://pubs.acs.org/doi/abs/10.1021/ ac991080w

Lavorenti A, Prata F, Regitano B (2003) Comportamento de pesticidas em solos: fundamentos. Tópicos especiais em ciência do solo. Sociedade Brasileira de Ciência do Solo, Viçosa, Brazil

Ling W, Xu J, Gao Y (2006) Dissolved organic matter enhances the sorption of atrazine by soil. Biol Fertil Soils 42:418-425. https:// doi.org/10.1007/s00374-006-0085-6

McBride B (1994) Química ambiental dos solos. Oxford University Press, Nova Iorque

Mitchell J, Simpson J (2013) High affinity sorption domains in soil are blocked by polar soil organic matter components. Environ Sci Technol 47:412-419. https://doi.org/10.1021/es303853x

Oliver P, Baldock A, Kookana S (2005) The effect of landuse on soil organic carbon chemistry and sorption of pesticides and metabolites. Chemosphere 60:531-541. https://doi.org/10.1016/j.chemo sphere.2005.01.027

Reemtsma T, Bredow A, Gehring M (1999) The nature and kinetics of organic matter release from soil by salt solutions. Eur J Soil Sci 50:53-64. https://doi.org/10.1046/j.1365-2389.1999.00212.x

Sarwar M, Anjum S, Khan MA (2018) Assessment of sustainable and biodegradable agricultural substrates for eminence production of cucumber for kitchen gardening. Int J Recycl Org Resíduos Agric. https://doi.org/10.1007/s40093-018-0222-x

Spark M, Swift S (2002) Effect of soil composition and dissolved organic matter on pesticide sorption. Sci Total Environ 298:147161. https://doi.org/10.1016/S0048-9697(02)00213-9

United Nations (2008) Relatório de Desenvolvimento Humano. http:// www.pnud.org.br/HDR/arquivos/RDHglobais/hdr2007-8-portu guese.pdf. Accessed Oct 2018

Zheng Q, Cooper F (1996) Adsorption, desorption and degradation of three pesticides in different soils. Arch Environ Contam Toxicol 30:15-20. https://doi.org/10.1007/BF00211324

Publisher's Note Springer Nature remains neutral with regard to jurisdictional claims in published maps and institutional affiliations. 